\title{
Remediation of Chromium Toxicity by FYM and Vermicompost in Rice (Oryza sativa)
}

\author{
Ramya Krishna Koka ${ }^{1 *}$, P.K. Sharma ${ }^{1}$, Jiten Behera ${ }^{1}$ and Gayathri Chalageri ${ }^{2}$
}

${ }^{1}$ Department of Soil Science and Agricultural Chemistry, ${ }^{2}$ Department of Agronomy, Institute of Agricultural Sciences, Banaras Hindu University, Varanasi, U.P.-221005, India

*Corresponding author

\section{A B S T R A C T}

Chromium is a serious heavy metal and it is considered as an environmental hazard. The contamination of the soil environment with chromium compounds is more and more

\section{Keywords}

Rice, Chromium,

FYM, Growth,

Vermicompost,

Yield

Article Info

Accepted:

15 January 2019

Available Online:

10 February 2019 frequently occurring problem throughout the world. Toxicity effects of chromium on growth and development as it decrease the growth and biomass of plant. A pot experiment was conducted in net house of Department of Soil Science and Agricultural Chemistry, Institute of Agricultural Sciences, Banaras Hindu University, Varanasi during 2015-16 to study the effect of FYM and vermicompost on growth and yield of rice in chromium contaminated soil. Five levels of chromium viz. 0, 20, 40, 60 and $80 \mathrm{ppm}$ with and without vermicompost @ 5 ton ha $^{-1}$ and farm yard manure @ 10 ton ha ${ }^{-1}$ were taken. Results indicated that growth parameters, yield attributes and yield of rice decreased with increasing $\mathrm{Cr}$ concentration $(0,20,40,60,80 \mathrm{ppm})$. The parameters like plant height, number of tillers/hill, productive tillers/hill, chlorophyll content, panicle length, number of grains/panicle, test weight, straw yield, grain yield and harvest index significantly increased with the application of vermicompost and FYM. Rice crop can withstand up to $80 \mathrm{ppm}$ of chromium with vermicompost and can tolerate up to $60 \mathrm{ppm}$ with FYM. Hence, toxic effect of $\mathrm{Cr}$ on rice crop may well be mitigated more effectively with vermicompost and FYM application.

\section{Introduction}

Chromium (VI) is toxic to agronomic plants at concentration of 0.5 to $5.0 \mathrm{mg} \mathrm{mL}^{-1}$ in nutrient solution and $5-100 \mathrm{mg} \mathrm{kg}-1$ in soil (Ali et al., 2013; Chrysochoou et al., 2012). Recently, the use of a variety of organic and inorganic amendments has attained a considerable attention for remediation of heavy metal-contaminated soils (Usman et al., 2013; Almaroai et al., 2014; Adrees et al., 2015; Rehman et al., 2015; Rizwan et al., 2016a). Organic and inorganic amendments are used for immobilization of metals in the soils with varying benefits but organic amendments could be better option due to 
improvement of physical, chemical, biological properties and fertility status of the soil (Park et al., 2011). The mobility and toxicity of $\mathrm{Cr}^{6+}$ can be reduced by converting it to the reduced state of $\mathrm{Cr}^{3+}$ by means of organic matter and inorganic reducing agents in the soil (Aceves et al., 2007; Kumar and Sharma, 2018). These Organic sources may be organic manures, green manure, rural wastes, crop residues, biofertilizers and vermicompost. The positive effect of vermicompost application on soil properties is well documented and established (Kumar et $a l .$, 2018). The immobilizing effect of organic amendments are thought to act through various complex processes e.g. formation of stable compounds with organic ligands, surface precipitation and ion exchange (Kumpiene et al., 2008; Ahmad et al., 2011a). Moreover organic amendments may enhance the soil fertility and microbial activity, leading to the amelioration of the soil quality as a whole. These overall modifications generally decrease the mobility and the bioavailability of trace elements, even if temporarily and thus promote the reestablishment of vegetation and increase plant growth (Madejon et al., 2006; Branzini and Zubillaga, 2012). The effect of organic amendments on the mobility and the bioavailability of metal(loid)s depends on the nature of the organic matter itself, its microbial degradability, its effects on soil chemical and physical proprieties, as well as on the particular soil type and metal(loid)s concerned (Angelova et al., 2013). Immobilization of metals in contaminated soils using amendments is a remediation technique that decreases mobility and phytoavailability of metals in the soils and their uptake by plants (Sabir et al., 2013; Rizwan et al., 2016b; Rehman et al., 2017).

Farm yard manure (FYM) is being used as the major source of organic manure in field crops. Limited availability of this manure is, however, an important constraint on its use as a source of nutrients. FYM positively controls the crop production and recovers properties of soil and it can be used to decrease heavy metal stress in plants. Farm yard manure (FYM) positively influence crop production, improved soil physical, chemical, and biological properties (Ould Ahmed et al., 2010; Alam et al., 2014) and can be used to reduce heavy metal hazards in plants (Yassen et al., 2007). Farm yard manure application to the soil could be used as an effective measure for reducing $\mathrm{Cr}$ toxicity to crop plants in $\mathrm{Cr}$ contaminated soils (Singh et al., 2007). The limited information is available in the literature related to the effect of FYM application on immobilization and detoxification of $\mathrm{Cr}$ in soil, bioavailability of $\mathrm{Cr}$, crop yield, and $\mathrm{Cr}$ uptake (Singh et al., 2007).

Vermicompost (VC) is an important source of rapidly emerging organic input. It is produced from various organic wastes and it is a rich source of enzymes, antibiotics, immobilized micro flora and growth hormones like gibberellins which regulate the growth of plants and microbes. Vermicompost is a rich source of microorganisms and nutrients and used a soil fertilizer or conditioner. It has a greatest ability to enhance the quality of growing plants and also increases biomass which could suggest that more metal toxicity is improved. However, information is hardly available on the phytotoxicity of $\mathrm{Cr}$ in cereals and its remedy. So, the pot experiment was taken for the study of toxic effects of $\mathrm{Cr}$ with amendments viz., FYM and Vermicompost to reduce the adverse effects of $\mathrm{Cr}$ on the growth, quality and yield of rice.The vermicompost contain high nutrient value, increases fertility of soil and maintains soil health (Suthar et al., 2005). Application of vermicompost in contaminated soil improves soil fertility and physical properties as well as helps in successful approach to 
phytoremediation (Zheljazkov and Warman, 2004; Jadia and Fulekar, 2008).

Rice is the most widely consumed staple food crop and a primary food source for 50\% of the world's population (Wang et al., 2013; Ramzani et al., 2016). At present, soil contamination of heavy metals including $\mathrm{Cr}$ renders a great threat to rice production and subsequently affects food safety. High $\mathrm{Cr}$ concentration in soil is toxic to rice, resulting in reduced growth, yield, and dry matter production (Qiu et al., 2010). In rice, most of the $\mathrm{Cr}$ was accumulated in roots, but still, a significant fraction can be transported into above ground tissues, including grains, which causes a health issue to human via food chain(Qiu et al., 2011). However very few comparative studies have been performed so far and the choice of a particular organic amendment in assisted phytostabilization strategies often remain empirical (Hattab et al., 2015).So, for remediation of chromium toxicityin rice, we have used certain organic amendments like Farm Yard Manure and vermicompost in this study.

\section{Materials and Methods}

Pot experiment was conducted in Net house of the Department of Soil Science and Agricultural Chemistry, Institute of Agricultural Sciences, Banaras Hindu University, Varanasi taking rice as a test crop in 2016-17 during kharif season, to study the effect of different $\mathrm{Cr}$ concentrations (0, 20, $40,50,60,80 \mathrm{ppm})$ with and without application of FYM and Vermicompost. Processed $10 \mathrm{~kg}$ soil was filled in each polythene lined pots. The pots were irrigated up to field capacity and moisture level is maintained. Pots were treated with required amount of $\mathrm{Cr}$ through potassium dichromate $\left(\mathrm{K}_{2} \mathrm{Cr}_{2} \mathrm{O}_{7}\right)$ i.e. $\mathrm{Cr}$ (VI), with five different levels like $(0,20,40,60,80 \mathrm{mg} / \mathrm{kg}$ soil) and maintained contamination for 15 days. After
15 days of application of chromium, the organic farmyard manure (FYM) i.e., as $50 \mathrm{gm} / 10 \mathrm{~kg}$ soil and vermicompost $(25 \mathrm{~g} / 10 \mathrm{~kg}$ soil) applied to the soil and mixed thoroughly. Pots were incubated for 15 days with organic amendments and watered at field capacity and four week old-seedlings were transplanted on august $1^{\text {st }}$ and five seedlings were transplanted in each pot. All the pots received uniform dose of NPK, and irrigation had supplied to maintain field capacity. The crop was grown up to maturity. Growth parameters, yield attributes and yield were studied before and after harvesting as per investigation required.

The height of plants was measured help of meter scale at 30, 60 and 90 days after transplanting from the base of the plant to the tip of the upper most fully opened leaf. Chlorophyll content of the rice plants was measured at 30, 60 and 90 days after transplanting by the use of chlorophyll meter in SPAD units.

After panicle emergence, the height was measured up to the tip of the panicle. Number of tillers/hill was counted from each pot at 30 , 60 and 90 days after transplanting total tillers/hill and productive tillers/hill from each pot was computed. Five panicles were randomly selected from plants in each pot and the length of panicle was measured from the neck node to the tip of the upper most spikelet and average length of panicle was recorded. Grains of five panicles of randomly selected from each pot were separated and counted and their mean value expressed as average grains per panicle as number of filled grains and number of unfilled grains. Grain samples were taken from the threshed and cleaned produce of each pot and 1000 grains were counted and weighed. Protein content (\%) in grain was worked out by multiplying the nitrogen content in grain by the factor 6.25 (A.O.A.C, 1995). 


\section{Results and Discussion}

\section{Effect of FYM and Vermicompost on growth parameters of rice in chromium contaminated soil}

\section{Plant height (cm)}

The height of rice plant in Cr-contaminated soil is depicted in table 1. It was observed that height of rice plant influenced by FYM and Vermicompost. The plant height generally increased from 30, 60, 90 DAT and there after a gradual decline was observed. It is apparent from the data that plant height was significantly affected by different levels of chromium at all growth stages. With increase in the chromium concentration $(0,20,40,60$, $80 \mathrm{ppm})$ the plant height has decreased respectively. Similar results were also reported by Nagarajan (2014).

Addition of amendments like FYM and Vermicompost showed that there is significant increase in plant height (30 DAT) compared to control pots. The highest plant height $(58.5 \mathrm{~cm})$ was found in treatment $\mathrm{Cr} 0$ $+\mathrm{VC}$ followed by the treatment $\mathrm{Cr} 0+\mathrm{FYM}$ i.e., $(56.3 \mathrm{~cm})$. On the other hand, the lowest values of these parameters were obtained from control pot with treatment Cr80 (49.1 $\mathrm{cm})$. The similar trend was noticed with plant height at 60DAT and 90 DAT except a slight increase in plant height and there after a decline in height observed. Interaction of chromium with organic amendments had shown non-significant effect on plant height.

The increase in plant height might be due to an adequate supply of nutrients by amendments. The availability of nutrients is due to improvement in important soil properties given by Ganal and Singh (1988), Singarum (1994). In the absence of any organic amendments, the rice growth was decreased due to the toxicity of Cr VI.

\section{Chlorophyll Content (SPAD)}

The data of chlorophyll content was recorded by SPAD at different observation days presented in Table 1. Perusal of data presented that chlorophyll content increased slowly from 30 to 60 DAT and there after a gradual decline was observed at 90 DAT and maturity. It is apparent from the data that chlorophyll content was significantly affected by different chromium levels at all growth stages. The increase in the chromium concentration $(0,20,40,60$ and $80 \mathrm{ppm})$ has decreased chlorophyll content respectively. Oxidative stress is induced by more concentration of chromium, which involves induction of lipid peroxidation in plants that cause severe damage to cell membranes. The oxidative stress is induced by chromium initiates the degradation of photosynthetic pigments which causes a decline in growth of the plant. High chromium concentration can disturb the chloroplast ultra-structure there by disturbing the photosynthetic process. $\mathrm{Cr}$ stress is one of the important factors that affect photosynthesis in terms of $\mathrm{CO}_{2}$ fixation, electron transport, photophosphorylation and enzyme activities said by Clijsters and Van Assche (1985). The Chromium toxicity in plants occurs by inhibiting the growth more or less, showing chlorosis. High chromium concentration inhibits photosynthesis and seriously inhibits the root growth reported by Dheeba and Sampathkumar (2012). The results of the pot experiments showed that chlorophyll content rice was significantly affected due to the application of organic amendments. The highest chlorophyll content (40.87) was observed with treatment $\mathrm{Cr} 0+\mathrm{VC}$ followed by treatment $\mathrm{Cr} 0+$ FYM (38.5). The plants grown on soil without any amendments Cr80 had shown yellowing of leaves. The application of vermicompost and FYM resulted in a significantly highest chlorophyll content of rice. A similar trend followed 
in60DAT but during 90 DAT and maturity gradual decline in chlorophyll content was observed due to toxicity effect of $\mathrm{Cr}$ VI. The interaction effect between chromium concentration levels and amendments on chlorophyll content was found non-significant in all growth stages. Application of FYM and VC provides all macronutrients as well as micronutrients that may help to increase the chlorophyll synthesis in the plants. Similar results were also reported by Anburani and Manivannan (2002).

\section{Number of tillers hill ${ }^{-1}$}

Data pertaining to number of tillers hill $^{-1}$ is presented in Table 2. The number of tillers hill $^{-1}$ increased slowly from 30 to 60 DAT and there after a gradual decline was observed. It is apparent from the data that production of tillers hill $^{-1}$ was significantly affected by different chromium levels at all growth stages. The increase in the chromium concentration $(0,20,40,60,80) \mathrm{ppm}$ has decreased total tillers hill ${ }^{-1}(10.2,9.4,8.0,6.8$, $5.3)$ respectively and productive tillers hill $^{-1}$, $(8.4,7.5,7.2,6.7,5.1)$ also have shown same trend. Similar results like Cr-treated rice plants showed stunted growth and produced less number of tillers and leaves compared to counterparts grown in control has reported by Ahmad et al., (2011b).

The results of the pot experiments showed that a number of tillers hill $^{-1}$ of rice and productive tillers hill $^{-1}$ were significantly affected due to the application of organic amendments. The highest total tillers hill ${ }^{-1}$ and productive tillers hill ${ }^{-1}$ were observed in all control pots of $\mathrm{Cr} 0+\mathrm{VC}$ followed by $\mathrm{CrO}+$ FYM. The application of vermicompost and FYM resulted in a significantly greater number of tillers hill $^{-1}$ and productive tillers/hill of rice. Organic sources offer more balanced nutrition to the plants, especially micro nutrients which has caused better tillering in plants grown with Vermicompost and FYM given by Amitava et al., (2008).

The interaction effect of $\mathrm{Cr}$ and amendments indicated that the adverse effect of $\mathrm{Cr}$ on tillers hill ${ }^{-1}$ and productive tillers hill ${ }^{-1}$ of rice could be alleviated to some extent by amendment application, especially with vermicompost addition. Significantly, the highest number of tillers hill ${ }^{-1}$ and productive tillers hill $^{-1}$ were recorded in treatment $\mathrm{Cr} 0$ $+\mathrm{VC}$; while the maximum tillers reduction was noted by 50 per cent over control at Cr80 level without amendment (Table 2). The interaction effect between chromium concentration levels and amendments on tillers hill $^{-1}$ was found non-significant in all growth stages.

All these growth parameters have reduced with an increase in chromium concentrations this is seen because when metal content of soil becomes high, the plant will lose its role, possibly because of the lethal exploit by the metal, and the uptake especially increases. Further, because of this improved uptake, metals will interrelate with various cellular mechanisms and they disturb the normal metabolic reactions of plants, producing cellular damage and the death of the plants in severe cases. The decrease in plant growth could be due to the reduction of photosynthetic pigments (Wani et al., 2006 and Sheoran et al., 1990).

Organic amendments are used for the improving soils fertility, enhancing plant growth and decreasing Phyto-available fractions of metals, where similar results reported by Walker et al., (2004). The variation in the above-mentioned parameters recorded might be attributed due to the availability of nutrients. Nutrient availability from organic sources is due to microbial action which is slow and steady and further through improved physical conditions of the 
soils as reported by Amitava et al., (2008) and Mirza et al., (2010).

Vermicompost showed better performance it might be due to the presence of plant growth substances identified as indole compounds which could be secreted into the cast and in turn increased plant growth compared to FYM similar result was reported by Atiyeh et al., (2002) and Chaoui et al., (2003). Available nutrient contents of vermicompost, as well as the rate of release, are much higher than that of FYM. The Higher occurrence of different beneficial microorganisms, production of growth promoting hormones, antibiotics, enzymes etc which helps in improvement of soil health and microorganisms were recorded with the application of vermicompost reported by Barik et al., (2006).

The results indicated that $\mathrm{Cr}$ affects all growth parameters of rice even though it was reported as an accumulator and tolerant for heavy metals, So upon addition of these organic amendments will reduce the toxicity caused by $\mathrm{Cr}$ and significantly increase the growth rate of plants.

\section{Effect of FYM and vermicompost on yield attributes of rice in chromium contaminated soil}

\section{Panicle length $(\mathrm{cm})$}

The application of chromium at different concentrations and organic amendments significantly influenced length of the panicle. The results presented in Table 3 showed that plant has slight variations and can withstand with an increase in the levels of chromium up to concentration $\mathrm{Cr} 20$ in control and with use of amendments rice can withstand up to treatment $\mathrm{Cr} 40$. It is evident from the results that panicle length varied from (17.5 to 22.2 $\mathrm{cm})$.Among organic amendments, maximum panicle length $(22.2 \mathrm{~cm})$ was found associated with the treatment $\mathrm{Cr} 0+\mathrm{VC}$ which was significantly higher than the application of Cr0+FYM $(20.2 \mathrm{~cm})$ panicle length. The interaction effect between chromium levels and organic sources in respect to the length of panicle and weight of panicle was nonsignificant.

\section{Number of grains panicle ${ }^{-1}$}

A significant effect on number of grains panicle $^{-1}$ was reported with application of different levels of chromium. Number of grains panicle ${ }^{-1}$ depicted in Table 3 which varied from 98.3 to 107 grains panicle ${ }^{-1}$. It was observed that number of grains/panicle decreased as level of chromium increased which was seen highest with control pot i.e., $\mathrm{Cr} 0$ followed by $\mathrm{Cr} 20$ which was higher over other treatments $\mathrm{Cr} 40, \mathrm{Cr} 60, \mathrm{Cr} 80$. It is evident from data that number of grains/panicle varied in FYM and vermicompost amended pots from130 to 109 grains panicle ${ }^{-1}$.These organic amendments significantly influenced the number of grains panicle ${ }^{-1}$ of rice. Maximum number of grains panicle $^{-1}$ (130 grains panicle $\left.{ }^{-1}\right)$ was recorded with $\mathrm{Cr} 0+\mathrm{VC}$ followed by $\mathrm{Cr} 0+$ FYM (120 grains panicle $\left.{ }^{-1}\right)$. The addition of these organic amendments has significantly increased the number of grains panicle ${ }^{-1}$. The interaction effect between chromium levels and organic amendments in respect to a number of grains panicle $^{-1}$ was found non-significant. The treatment of $\mathrm{Cr} 0+\mathrm{VC}$ was on par with treatment $\mathrm{Cr} 20+\mathrm{VC}$.

\section{0 grains weight $(\mathrm{g})$}

The data pertaining to 1000 grains weight provided in Table 3 varies from $(21.7 \mathrm{~g})$ in $\mathrm{Cr} 0$ to $(16.0 \mathrm{~g})$ in $\mathrm{Cr} 80$ in control treatments without amendments. The data also exhibited that higher 1000 grains weight was found at $\mathrm{Cr} 0, \mathrm{Cr} 20$ as compared to $\mathrm{Cr} 60$ and $\mathrm{Cr} 80$ 
without amendments.

FYM and vermicompost amendments significantly influenced 1000 grains weight of rice. Maximum 1000 grains weight $(24.0 \mathrm{~g})$ was recorded with treatment $\mathrm{Cr} 0+\mathrm{VC}$ followed by $\mathrm{Cr} 0+\mathrm{FYM}(22.2 \mathrm{~g})$. The addition of these organic amendments has significantly increased the 1000 grains weight. However, treatment control $(\mathrm{Cr} 0+\mathrm{VC})$ recorded 1000 grains weight on par with the treatment $(\mathrm{Cr} 20+\mathrm{VC})$. The interaction effect between chromium levels and FYM and vermicompost amendments in respect to 1000 grains weight was found non-significant.

All these yield attributes like panicle number, grains panicle ${ }^{-1}, 1000$ grain weight, increased with the addition of vermicompost. It was attributed due to the quick nutrient absorption by plants compared to FYM. Significant differences were observed in yield attributes of rice, it might be due to less nutrient capacity of organic manures which did not meet the requirement as reported by Mirza et al.,(2010). The improved growth coupled with the transport of photosynthates towards reproductive structure might have increased the yield attributes and yield due to organic addition (Manivannan and Sriramachandrasekharan, 2009).

The results indicated that $\mathrm{Cr}$ affects the yield attributes of rice even though it was reported as a hyper accumulator and tolerant for heavy metals. $\mathrm{Cr}$ adversely affects the yield attributes of rice and the FYM and vermicompost amendments alleviated the toxicity caused by $\mathrm{Cr}$ and significantly increase the yield attributes and yield of rice plants.

\section{Harvest index (\%)}

Harvest index of rice affected by chromium levels and organic amendments has been compiled and shown in figure 1 which revealed that harvest index varies from (46.9 $\%)$ in $\mathrm{Cr} 0$ to $(41.8 \%)$ in $\mathrm{Cr} 80$. However, higher harvest index seen in treatment $\mathrm{Cr} 0$ which was followed by the treatment $\mathrm{Cr} 20$ and decreased upon increasing the concentration of chromium.

Different organic amendments significantly influenced harvest index of rice. Maximum harvest index was recorded with treatment $\mathrm{Cr} 0+\mathrm{VC}(49.88 \%)$ followed by $\mathrm{Cr} 0+\mathrm{FYM}$ $(49.43 \%)$.The addition of these organic amendments has significantly increased the harvest index. The treatment $\mathrm{Cr} 0+\mathrm{VC}$ found at par with $\mathrm{Cr} 20+\mathrm{VC}$ and $\mathrm{Cr} 0+\mathrm{FYM}$. There was a significant difference in the extent of $\mathrm{Cr}(\mathrm{VI})$ reduction among the soils treated with organic amendments (Bolan and Thiyagarajan,2001and Bolan et al., 2003).Interaction effect between chromium levels and organic amendments in respect to harvest index was found non-significant.

\section{Effect of FYM and vermicompost on grain} and straw yield of rice in chromium contaminated soil

The yield of grain and straw has been depicted in the Table 5 and 6 respectively. An adverse direct effect on rice grain yield was shown by application of $\mathrm{Cr}$. The lowest value (20.37 $\mathrm{g} \mathrm{pot}^{-1}$ ) found in the treatment at Cr80 with a reduction in the yield by 23 per cent over control $\left(26.7 \mathrm{~g} \mathrm{pot}^{-1}\right)$.

Similar results were also reported in case of the straw yield of rice due to the direct effect of $\mathrm{Cr}$ (Table 6). The highest reduction in rice straw yield due to direct effect was observed at Cr80 (26.11g pot-1)by 10 per cent over corresponding to control $\left(29.29 \mathrm{~g} \mathrm{pot}^{-1}\right)$. The beneficial effect of $\mathrm{Cr}$ was seen at lower level up $\mathrm{Cr} 20$ or $\mathrm{Cr} 40$ on rice which could be attributed to increased absorption of nutrients like $\mathrm{K}, \mathrm{Ca}$ and $\mathrm{Mg}$, while at very higher $\mathrm{Cr}$ concentration it might have adversely affected 
due to phytotoxicity. Similar results were also observed by Parmar and Patel (2015). The $\mathrm{Cr}$ is inhibitory to metabolism and acts on a contributory factor in phytotoxicity of wheat (Sharma et al., 1995).

$\mathrm{Cr}$ affects most of biochemical and physiological processes in plants consequently productivity and yield are also affected (Kumar et al., 2016). Grain yield of rice is enhanced due to the direct effect of both the amendments FYM and vermicompost over control by 10 and 16 per cent, respectively which is evident in Table 5.

Similar results were also observed in straw yield of rice due to organic amendments application reported in Table 6. The improvement in yield of rice could be attributed to the addition of amendment viz., FYM and Vermicompost to the soil, which increased the availability of nutrients due to improvement in important soil properties as reported by Ganal and Singh (1988) and Singarum (1994).

The interaction effect between $\mathrm{Cr}$ and amendments like FYM and VC was found significant. The adverse effect of $\mathrm{Cr}$ on the yield of rice could be alleviated to some extent by amendment application, especially with vermicompost addition.

Significantly, the highest rice grain yield (31.7g) was recorded at treatment $\mathrm{Cr} 0+\mathrm{VC}$; while the maximum yield reduction was noted by 35 per cent over control at Cr80 level (20.37g) without amendment (Table 5).

Table.1 Effect of FYM and Vermicompost on plant height and chlorophyll content (SPAD) of rice in chromium contaminated soil

\begin{tabular}{|l|r|r|r|r|r|r|}
\hline \multirow{2}{*}{ Treatments } & \multicolumn{4}{|c|}{ Plant height (cm) } & \multicolumn{3}{|c|}{ Chlorophyll content (SPAD) } \\
\cline { 2 - 7 } & 30 DAT & 60 DAT & 90 DAT & 30 DAT & 60 DAT & 90 DAT \\
\hline Cr 0 & 52.9 & 78.9 & 99.0 & 35.18 & 32.19 & 25.33 \\
\hline Cr20 & 52.8 & 78.3 & 97.5 & 33.50 & 31.13 & 22.00 \\
\hline Cr 40 & 51.9 & 77.1 & 96.0 & 32.84 & 28.73 & 18.67 \\
\hline Cr 60 & 50.8 & 75.2 & 93.4 & 31.44 & 27.20 & 15.33 \\
\hline Cr 80 & 49.1 & 73.6 & 91.2 & 30.56 & 24.10 & 11.33 \\
\hline Cr0+FYM & 56.3 & 81.9 & 102.1 & 38.50 & 33.29 & 27.00 \\
\hline Cr 20+FYM & 55.7 & 79.9 & 100.6 & 37.80 & 31.47 & 23.33 \\
\hline Cr 40+FYM & 54.8 & 77.5 & 98.8 & 36.31 & 29.07 & 19.33 \\
\hline Cr60+FYM & 53.3 & 76.6 & 97.5 & 34.96 & 26.59 & 14.67 \\
\hline Cr 80+FYM & 51.7 & 75.1 & 93.9 & 32.97 & 25.43 & 13.67 \\
\hline Cr0+VC & 58.5 & 84.7 & 104.4 & 40.87 & 33.96 & 27.67 \\
\hline Cr20+VC & 57.6 & 83.5 & 103.8 & 38.84 & 32.40 & 24.67 \\
\hline Cr40+VC & 56.7 & 83.0 & 101.9 & 38.01 & 29.44 & 22.00 \\
\hline Cr60+VC & 55.6 & 81.4 & 99.5 & 36.61 & 26.94 & 18.67 \\
\hline Cr80+VC & 54.2 & 79.4 & 97.4 & 34.94 & 24.50 & 16.33 \\
\hline SEm & 0.6 & 0.5 & 0.6 & 0.35 & 0.31 & 1.56 \\
\hline CD (P=0.01) & 1.7 & 1.6 & 1.8 & 1.02 & 0.89 & 4.50 \\
\hline
\end{tabular}


Table.2 Effect of FYM and Vermicompost on number of tillers in chromium contaminated soil

\begin{tabular}{|l|l|l|r|r|}
\hline Treatments & 30DAT & 60DAT & Total Tillers/Hill & Productive Tillers/Hill \\
\hline Cr 0 & 7.5 & 9.5 & 10.2 & 8.4 \\
\hline Cr20 & 6.4 & 9.1 & 9.4 & 7.5 \\
\hline Cr 40 & 5.8 & 7.7 & 8 & 7.2 \\
\hline Cr 60 & 4.8 & 7.1 & 6.8 & 6.7 \\
\hline Cr 80 & 4.1 & 5.5 & 5.3 & 5.1 \\
\hline Cr0+FYM & 8.1 & 13.0 & 13.1 & 10.1 \\
\hline Cr 20+FYM & 7.5 & 12.3 & 12.2 & 9.7 \\
\hline Cr 40+FYM & 7.1 & 10.8 & 11.9 & 9.3 \\
\hline Cr60+FYM & 6.3 & 9.3 & 10.5 & 8.1 \\
\hline Cr 80+FYM & 5.4 & 7.9 & 9.4 & 6.2 \\
\hline Cr0+VC & 9.2 & 14.8 & 15.1 & 12.3 \\
\hline Cr20+VC & 8.8 & 13.2 & 14.1 & 11.3 \\
\hline Cr40+VC & 8.0 & 12.8 & 13.5 & 10.9 \\
\hline Cr60+VC & 7.1 & 12.2 & 12.9 & 9.8 \\
\hline Cr80+VC & 6.5 & 11.5 & 11.9 & 8.2 \\
\hline SEm \pm & 0.3 & 0.4 & 0.4 & 0.2 \\
\hline CD $(\mathbf{P}=\mathbf{0 . 0 1})$ & 1.0 & 1.2 & 1.1 & 0.5 \\
\hline
\end{tabular}

Table.3 Effect of FYM and Vermicompost on yield attributes of rice in chromium contaminated soil

\begin{tabular}{|l|r|r|r|r|r|}
\hline Treatments & $\begin{array}{l}\text { Panicle length } \\
(\mathbf{c m})\end{array}$ & $\begin{array}{l}\text { Number of } \\
\left.\text { panicles } \mathbf{p o t}^{-\mathbf{1}}\right)\end{array}$ & $\begin{array}{l}\text { No. of } \\
\text { Grains/panicle }\end{array}$ & $\begin{array}{l}\text { Unfilled } \\
\text { grains /panicle }\end{array}$ & $\begin{array}{l}\text { Test weight } \\
\text { (or) } \\
\text { 1000 grain } \\
\text { weight } \mathbf{( g )}\end{array}$ \\
\hline Cr 0 & 18.9 & 51.0 & 107 & 7.7 & 21.6 \\
\hline Cr20 & 18.3 & 47.0 & 105 & 8.0 & 19.3 \\
\hline Cr 40 & 18.0 & 40.0 & 103.3 & 10.0 & 18.7 \\
\hline Cr 60 & 17.7 & 34.0 & 101.3 & 13.7 & 17.5 \\
\hline Cr 80 & 17.5 & 26.5 & 98.3 & 15.0 & 16.0 \\
\hline Cr0+FYM & 20.2 & 65.5 & 120.7 & 5.0 & 22.9 \\
\hline Cr 20+FYM & 20.1 & 61.0 & 119.3 & 7.3 & 21.3 \\
\hline Cr 40+FYM & 20.0 & 59.5 & 116.7 & 9.7 & 20.2 \\
\hline Cr60+FYM & 19.0 & 52.5 & 111.7 & 11.0 & 18.8 \\
\hline Cr 80+FYM & 18.4 & 47.0 & 109.3 & 13.0 & 17.3 \\
\hline Cr0+VC & 22.2 & 75.5 & 130.7 & 4.0 & 24.4 \\
\hline Cr20+VC & 21.8 & 70.5 & 128.7 & 6.7 & 22.8 \\
\hline Cr40+VC & 21.7 & 67.5 & 122.7 & 7.0 & 21.7 \\
\hline Cr60+VC & 19.9 & 64.5 & 120.3 & 7.7 & 19.7 \\
\hline Cr80+VC & 19.3 & 59.5 & 116 & 10.3 & 18.8 \\
\hline SEm + & 0.5 & 2.0 & 1.46 & 4.4 & 0.4 \\
\hline CD (P=0.01) & 1.5 & 5.5 & 4.21 & 1.3 \\
\hline
\end{tabular}


Table.4 Effect of FYM and vermicompost on protein content and protein yield of rice in chromium contaminated soil

\begin{tabular}{|l|c|c|}
\hline \multicolumn{1}{|c|}{ Treatments } & Protein content (\%) & Protein yield $\left(\mathrm{g} \mathrm{pot}^{\mathbf{- 1}}\right)$ \\
\hline Cr 0 & 6.75 & 177.30 \\
\hline Cr20 & 7.21 & 181.41 \\
\hline Cr 40 & 6.67 & 161.38 \\
\hline Cr 60 & 6.04 & 136.15 \\
\hline Cr 80 & 3.54 & 72.08 \\
\hline Cr0+FYM & 9.21 & 268.28 \\
\hline Cr 20+FYM & 8.96 & 252.77 \\
\hline Cr 40+FYM & 8.81 & 233.26 \\
\hline Cr60+FYM & 8.46 & 213.99 \\
\hline Cr 80+FYM & 6.88 & 168.77 \\
\hline Cr0+VC & 11.56 & 362.62 \\
\hline Cr20+VC & 11.67 & 355.10 \\
\hline Cr40+VC & 10.88 & 308.39 \\
\hline Cr60+VC & 10.42 & 272.45 \\
\hline Cr80+VC & 10.00 & 253.38 \\
\hline SEm \pm & 0.48 & 12.66 \\
\hline CD (P=0.01) & 1.38 & 36.56 \\
\hline
\end{tabular}

Table.5 Effect of FYM and Vermicompost on grain yeild $\left(\mathrm{g} \mathrm{pot}^{-1}\right)$ of rice in chromium contaminated soil

\begin{tabular}{|l|l|l|l|l|}
\hline Treatments & Control & FYM & VC & Mean \\
\hline Cr 0 & 26.27 & 29.13 & 31.37 & 28.92 \\
\hline Cr 20 & 25.17 & 28.23 & 30.43 & 27.94 \\
\hline Cr 40 & 24.20 & 26.50 & 28.37 & 26.36 \\
\hline Cr 60 & 22.57 & 25.30 & 26.13 & 24.67 \\
\hline Cr 80 & 20.37 & 24.53 & 25.33 & 23.41 \\
\hline Mean & 23.71 & 26.73 & 28.32 & 26.26 \\
\hline & & & & \\
\hline & SEm \pm & CD $(\mathrm{P}=0.01)$ & & \\
\hline C & 0.12 & 0.35 & SIG & \\
\hline A & 0.09 & 0.27 & SIG & \\
\hline C*A & 0.21 & 0.61 & SIG & \\
\hline
\end{tabular}


Table.6 Effect of FYM and Vermicompost on straw yield $\left(\mathrm{g} \mathrm{pot}^{-1}\right)$ of rice in chromium contaminated soil

\begin{tabular}{|l|l|l|l|l|}
\hline Treatments & Control & FYM & VC & Mean \\
\hline Cr 0 & 29.29 & 29.59 & 31.48 & 30.12 \\
\hline Cr 20 & 29.67 & 30.27 & 30.47 & 30.14 \\
\hline Cr 40 & 28.30 & 29.89 & 30.20 & 29.46 \\
\hline Cr 60 & 26.49 & 28.46 & 30.30 & 28.42 \\
\hline Cr 80 & 26.11 & 27.25 & 29.21 & 27.52 \\
\hline Mean & 27.97 & 29.09 & 30.33 & 29.13 \\
\hline & & & & \\
\hline & SEm \pm & CD $(\mathrm{P}=0.01)$ & & \\
\hline C & 0.23 & 0.65 & SIG & \\
\hline A & 0.17 & 0.50 & SIG & \\
\hline C*A & 0.39 & 1.13 & SIG & \\
\hline
\end{tabular}

Fig.1 Effect of FYM and Vermicompost on harvest index of rice in chromium contaminated soil

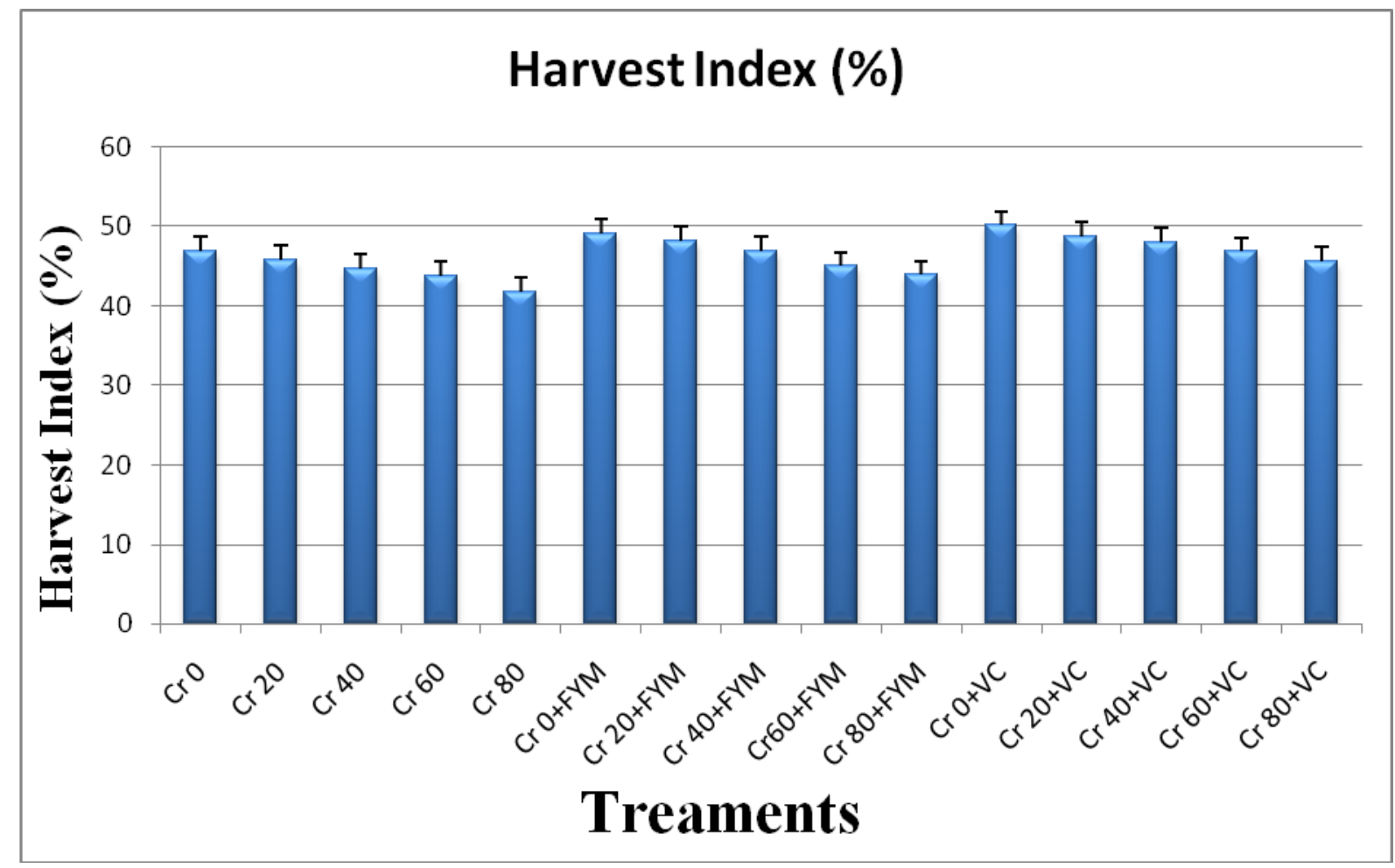

This beneficial effect of amendments like FYM and VC also ascribed to increased microbial activity which might have helped in reduction of the toxic form $\left(\mathrm{Cr}^{6+}\right)$ to non-toxic form $\left(\mathrm{Cr}^{3+}\right)$ by microbial activity, by acting as electron donors, and $\mathrm{O}_{2}$ level of the soil is lowered thereby creating reduced conditions. Almost similar trend was noticed for the straw yield of rice as an influence by the direct effect of $\mathrm{Cr}$ as well as interaction effect of $\mathrm{Cr}$ and amendments (Table 6). These results were in agreement with the result of Bolan et 
al.,(2003) and Yuji et al., (2004). This improvement in yield could be mainly attributed due to the reduction in the bioavailability of $\mathrm{Cr}$ and thus reduce toxic effects of $\mathrm{Cr}$ in the soil. Bioavailability of metal in the soil environment and soil particles is said to be the fraction of the total metal in the interstitial pore water that is available to the receptor organism. More specifically, it refers to the biologically available fraction (or pool) that can be taken up by an organism and can react with its metabolic machinery. By immobilization of metals, the bioavailability of metal can be reduced. This could be achieved by the addition of organic amendments where these amendments increase the immobilization of metal through adsorption reactions, the formation of organo-chromic complexes or reduction of toxicity in soil or by chelation. The grain and straw yield has been dropped after applying heavy metals which have been accredited to the toxic effects of metals on the propagation of roots and shoots. The characters of rice vary under various treatments of chromium. High organic matter and macro and micronutrients enhance both the soil physical, chemical and biological properties and the plant yield. FYM increased the organic carbon of the soil and it improves both soil quality and growth of plants (Hati et al., 2007) and enhanced accessibility of all type of nutrients in soil because of organic and inorganic combinations (Yadav et al., 2000).

\section{Effect of chromium levels and organic sources on the quality parameter of rice}

\section{Protein content $(\%)$}

The crude protein content ranged from 3.54 to 6.75 per cent. The plants from control treatment $(\mathrm{Cr} 80)$ had the lowest content (3.54 $\%$ ) of crude protein. A significant increase in crude protein content was observed due to the application of vermicompost. Only a small variation was observed with FYM. Scrutiny of the data showed that maximum protein content $(11.56 \%)$ recorded in rice grain with the treatment $\mathrm{Cr} 0+\mathrm{VC}$ followed by treatment Cr0+FYM (9.21\%) compared the treatment $\mathrm{Cr} 0$ alone(6.75\%). This may be due to the high availability of nitrogen for protein synthesis. FYM amendment showed the better supply of nitrogen, phosphorus, potassium, and enhanced soil physical environment than an amendment one as reported by Bhattacharyya et al., (2008). The reduction in protein content may be due to the poor availability of nitrogen, similar results were also reported by Muthusamy and Jayabalan (2001) (Table 4).

\section{Protein yield $\left(\mathrm{g} \mathrm{pot}^{-1}\right)$}

There is marked variation in the protein yield of rice grain. The protein yield in grain differed significantly due to chromium concentrations. Maximum protein yield was noticed highest $\left(177.30 \mathrm{~g} \mathrm{pot}^{-1}\right)$ with the treatment $\mathrm{Cr} 0$ applied which was significantly superior over all other higher chromium levels. However, control, $20 \mathrm{ppm}$ and 40ppm chromium differed significantly among them regarding protein yield.

Scrutiny of the data showed that maximum protein yield $\left(362.6 \mathrm{~g} \mathrm{pot}^{-1}\right)$ ) recorded in rice grain with the treatment $\mathrm{Cr} 0+\mathrm{VC}$ followed by treatment $\left.\mathrm{Cr} 0+\mathrm{FYM} \quad\left(268.28 \mathrm{~g} \operatorname{pot}^{-1}\right)\right)$ compared the treatment $\mathrm{Cr} 0$ alone $\left(177 \mathrm{~g}\right.$ pot $^{-}$ $\left.{ }^{1}\right)$. Organic manures increased the plant growth and yield as well as the soil quality. The mineral elements such as nitrogen, phosphorus, potassium, calcium, magnesium, manganese, iron, copper and zinc content of paddy are gradually decreased with the increase in chromium concentrations.

The decrease in the protein content of Brassica juncea under $\mathrm{Cd}$ and $\mathrm{Pb}$ stress has 
been reported by John et al., (2009). These heavy metals may cause fragmentation of proteins due to reactive oxygen species, thus, leading to declining in the protein content. Due to lowest oxidative stress in vermicompost and FYM amended the soil, plant protein content was highest under this amendment compared to others.

In conclusion, the present study indicated that $\mathrm{Cr}$ affects the growth, quality and yield attributes of rice even though it was reported as a hyper accumulator and tolerant for heavy metals. $\mathrm{Cr}$ adversely affects the growth, yield attributes and yield of rice. Application of FYM and vermicompost alleviated the toxicity of $\mathrm{Cr}$ and significantly increase the growth, yield attributes and yield of rice plants. All the growth parameters and yield attributes like panicle number, grains /panicle, 1000 grain weight, increased with the addition of FYM vermicompost. It was attributed due to the quick nutrient absorption by plants compared to FYM. The improved growth coupled with the transport of photosynthates towards reproductive structure might have increased the yield attributes and yield due to organic addition.

\section{References}

Aceves, M.B., Velasquez, R.O. and Vazquez, R.R.2007. Effects of $\mathrm{Cr}^{3+}, \mathrm{Cr}^{6+}$ and tannery sludge on $\mathrm{C}$ and $\mathrm{N}$ mineralization and microbial activity in semi-arid soils. Journal of Hazardous Materials.143:522-531.

Adrees, M., Ali, S., Rizwan, M., Rehman, M.Z., Ibrahim, M., Abbas, F., Farid, M., Qayyum, M.K. and Irshad, M.K. 2015. Mechanisms of silicon-mediated alleviation of heavy metal toxicity in plants: a review. Ecotoxicology and Environmental Safety.119: 186-197.

Ahmad, H.R., Ghafoor, A., Corwin, D.L., Aziz, M.A. and Saifullah, S.M. 2011a. Organic and inorganic amendments affect soil concentration and accumulation of cadmium and lead in wheat in calcareous alkaline soils. Communications in Soil Science and Plant Analysis.42:111-122.

Ahmad, M., Wahid, A., Ahmad, S. S., Butt, Z. A. and Tariq, M. 2011 b. Ecophysiological responses of rice (Oryza sativa L.) to hexavalent chromium. Pakistan Journal Botany. 43(6): 2853-2859.

Alam, M.S., Mishra, A.K., Singh, K., Singh, S.K. and David, A. 2014.Response of Sulphur and FYM on Soil PhysicoChemical Properties and Growth, Yield and Quality of Mustard (Brassica Nigra L.).Journal of Agricultural Physics.14(2): 156-160.

Ali, Z., Malik, R.N. and Qadir, A.2013. Heavy metals distribution and risk assessment in soils affected by tannery effluents. Chemistry and Ecology.29:676-692.

Almaroai, Y.A., Usman, A.R.A., Mahtab, A., Deok, H.M., Ju-Sik, C., Young, K.J., Choong, J., Sang, S.L. and Ok, Y.S.2014. "Effects of biochar, cow bone, and eggshell on $\mathrm{Pb}$ availability to maize in contaminated soil irrigated with saline water. Environmental Earth Sciences.71: 1289-1296.

Amitava, R., Sarkar, N.C. and Sen, D. 2008. Influence of organic manures on productivity of two varieties of Rice. Journal of Central European Agriculture. 9(4): 629-634.

Anburani, A. and Manivannan, K. 2002.Effect of integrated nutrient management on growth in brinjal (Solanum melongena L.) cv. Annamalai. South Indian Horticulture Journal. 50(4/6): 377-386.

Angelova, V.R., Akova, V.I., Artinova, N.S. and Ivanov, K.I.2013.The effect of organic amendments on soil chemical 
characteristics. Bulgarian Journal of Agricultural Science.19: 958-971.

A.O.A.C. 1995.Official and tentative methods of analysis. Association of Official Analytical Chemist International.16th Edition, Virginia (USA).

Atiyeh, R.M., Lee, S., Edward, C.A., Arancon, N.Q. and Metzger, J.D. 2002. The influence of humic acids derived from earth worms processed organic wastes on plant growth. Bioresearch Technology.84: 7-14.

Barik, A.K., Das, A., Giri, A.K.and Chattopadhyay, G.N. 2006. Effect of integrated plant nutrient management on growth, yield and production economics of wet season rice (Oryza sativa). Journal of Agricultural Science.76(11): 657-60.

Bhattacharyya, T., Pal, D.K., Chandran, P., Ray, S.K., Mandal, C. and Telpande, B. 2008. Soil carbon storage capacity as a tool to priorities areas for carbon sequestration. Current Science.95: 482494.

Bolan, N.S., Adriano, D.C., Natesan, R. and Koo, B.J. 2003.Effect of organic amendments on the reduction and phytoavailability of chromate in mineral soil. Journal of Environmental Quailty.32: 120-128.

Bolan, N.S. and Thiyagarajan, S. 2001. Retention and plant availability of chromium in soils as affected by lime and organic amendments. Australian Journal of Soil Research.39: 1091-1103.

Branzini, A. and Zubillaga, M.S. 2012.Comparative Use of Soil Organic and Inorganic Amendments in Heavy Metals Stabilization. Applied and Environmental Soil Science, 7.

Chaoui, I., Zibiliske, M. and Ohno, T. 2003. Effects of earth worm casts and compost on soil microbial activity and plant nutrient availability. Soil Biology andBiochemistry.35:295-302.
Chrysochoou, M., Johnston, C.P.andDahal, G. 2012.A comparative evaluation of hexavalent chromium treatment in contaminated soil by calcium polysulfide and green-tea nanoscale zero-valent iron. Journal of Hazardous Materials.201:33-42.

Clijsters, H. and Van Assche, F. 1985. Inhibition of photosynthesis by heavy metals. Photosynthesis Residence.7:3140.

Dheeba, B. and Sampathkumar, P. 2012.A comparative study on the phytoextraction of five common plants against Chromium Toxicity. Oriental Journal of Chemistry.28(2): 867-879.

Ganal, B. A. and Singh, C. M. 1988. Effect of farm yard manure applied in rice-wheat rotation on physico-chemical properties of soils. Indian Journal of Agronomy.33(3):327-329.

Hati, K. M., Swarup, A., Dwivedi, A. K., Misra, A. K. and Bandyopadhyay, K. K. 2007.Changes in soil physical properties and organic carbon status at the topsoil horizon of a vertisol of central India after 28 years of continuous cropping, fertilization and manuring. Agriculture, Ecosystems and Environment. 119(1-2): 127-134.

Hattab, N., Heino, M.M., Faure, O. and Bouchardon, J.L. 2015. Effect of fresh and mature organic amendments on the phytoremediation of technosols contaminated with high concentrations of trace elements. Journal of Environmental Management, Elsevier. 159:37-47.

Jadia, C.D. and Fulekar, M.H. 2008. Phytoremediation: the application of Vermicompost to remove zinc, cadmium, copper, nickel and lead by sunflower plant. Environmental Engineering and Management Journal. 7(5): 547-558.

John, R., Ahmad, P., Gadgil, K. and Sharma, 
S. 2009. Heavy Metal Toxicity: Effect on Plant Growth, Biochemical Parameters and Metal Accumulation by Brassica juncea L. International Journal Plant Production. 3: 65-76.

Kumar, A., Dhyani, B.P., Kumar, V., Rai, A., Kumar, A.andKaramveer2018. Nutrient Uptake in Rice Crop as Influenced by Vermicompost and Nitrogen Application. International Journal of Current Microbiology and Applied Sciences. 7(3): 558-569.

Kumar, V. and Sharma, P.K. 2018. Augmentation of nitrogen and phosphorous mineralization in chromium contaminated soils using organic amendments. International Journal of Chemical Studies. 6(2): 3417-3422.

Kumar, V., Suryakant, Sharma, P.K., Kumar, S. and Kumar, N. 2016. Effect of chromium toxicity on plants: A review. Agriways. 4(1): 107-120.

Kumpiene, J., Lagerkvist, A. and Maurice, C. 2008. Stabilization of $\mathrm{As}, \mathrm{Cr}, \mathrm{Cu}, \mathrm{Pb}$, and $\mathrm{Zn}$ in soil using amendments: A review. Waste Management. 28: 215225.

Madejon, P, De Mora, A.P., Felipe, E., Burgos, P., and Cabrera, F. 2006. Soil amendments reduce trace element solubility in a contaminated soil and allow regrowth of natural vegetation. Environmental Pollution. 139(1): 40-52.

Manivannan, R. and Sriramachandrasekharan, M.V. 2009. Response of lowland rice to addition of organics and mineral $\mathrm{N}$ grown on TypicHaplusterts soil. Journal of Applied Sciences Research. 5(11): 1988-1991.

Mirza, H., Ahamed, K.U., Rahmatullah, N.M. Akhter, N., Nahar, K. and Rahman, M.L. 2010.Plant growth characters and productivity of wet land rice (Oryza sativa $L$ ) as affected by application of different manures. Emirates Journal of
Food and Agriculture. 22(1): 46-58.

Muthusamy, A. and Jayabalan, N. 2001. Effect of factory effluents on physiological and biochemical contents of Gossypium hirsutum L. Journal of Environmental Biology.22(4): 237-242.

Nagarajan, M. 2014. Effect of chromium on growth, biochemicals and nutrient accumulation of paddy (Oryza sativa L.).International Letters of Natural Sciences. Pp. 18.

Ould Ahmed, B.A., Inoue, M. and Moritani, S. 2010.Effect of saline water irrigation and manure application on the available water content, soil salinity, and growth of wheat. Agricultural Water Management. 97: 165-170.

Park, J.H., Lamb, D., Paneerselvam, P., Choppala, G., Bolan, N. and Chung, J.W. 2011. Role of organic amendments on enhanced bioremediation of heavy metal (loid) contaminated soils. Journal of Hazardous Materials. 185(2): 549574.

Qiu, B., Zeng, F., Xue, D., Zhou, W., Ali, S. and Zhang, G. 2011.QTL mapping for chromium-induced growth and zinc, and chromium distribution in seedlings of rice DH population. Euphytica. 181: 429-439.

Qiu, B.Y., Zhou, W.H., Xue, D.W., Zeng, F.R., Ali, S. and Zhang, G.P. 2010. Identification of Cr-tolerant lines in a rice (Oryza sativa) DH population. Euphytica. 174:199-207

Ramzani, P.M.A., Khan, W.D., Iqbal, M., Kausar, S., Ali, S., Rizwan, M. and Virk, Z.A. 2016.Effect of different amendments on rice (Oryza sativa L.) growth, yield, nutrient uptake and grain quality in Ni-contaminated soil. Environmental Science and Pollution Research, DOI 10.1007/s11356-0167038-x

Rehman, M.Z., Khalid, H., Akmal, F., Ali, S., Rizwan, M., Qayyum, M.F., Iqbal, M., 
Khalid, M.U. and Azhar, M. 2017. Effect of limestone, lignite and biochar applied alone and combined on cadmium uptake in wheat and rice under rotation in an effluent irrigated field. Environmental Pollution. 227: 560-568.

Rehman, M.Z.,Rizwan, M., Ghafoor, A., Naeem, A., Ali, S., Sabir, M. and Qayyum, M.F. 2015. Effect of inorganic amendments for in situ stabilization of cadmium in contaminated soil and its phyto-availability to wheat and rice under rotation. Environmental Science and Pollution Research. 22: $16897-$ 16906.

Rizwan, M., Ali, S., Qayyum, M.F., Ibrahim, M., Rehman, M.Z., Abbas, T. and Ok, Y.S. 2016b. Mechanisms of biocharmediated alleviation of toxicity of trace elements in plants: a critical review. Environmental Science and Pollution Research. 23: 2230-2248.

Rizwan, M., Meunier, J.D., Davidian, J.C., Pokrovsky, O.S., Bovet, N. and Keller, C. 2016a. Silicon alleviates Cd stress of wheat seedlings (Triticum turgidum L. cv. Claudio) grown in hydroponics. Environmental Science and Pollution Research. 23: 1414-1427.

Sabir, M., Hanafi, M.M., Aziz, T., Ahmad, H.R., Rehman, M.Z., Saifullah, Murtaza, G. and Hakeem, K.R. 2013.Comparative effect of activated carbon, pressmud and poultry manure on immobilization and concentration of metals in maize (Zea mays) grown on contaminated soil. International Journal of Agriculture and Biology. 15(3): 559564.

Singarum, P. 1994. Effect of coil pith as an amendment for tannary polluted soil. Madras Agricultural Journal. 81(10): 548-549.

Sharma, D. C., Chatterjee, C. and Sharma, C. P. 1995.Chromium accumulation and its effects on wheat (Triticum aestivum L. cv. HD 2204) metabolism. Plant Science. 111(2): 145-151.

Sheoran, I. S., Singal, H. R. and Singh, R. 1990. Effect of cadmium and nickel on photosynthesis and the enzymes of the photosynthetic carbon reduction cycle in pigeonpea (Cajanus cajan L.). Photosynthesis Research. 23(3): 345351.

Singh, G., Brar, M. S. and Malhi, S. S. 2007.Decontamination of Chromium by Farm Yard Manure Application in Spinach Grown in Two Texturally Different Cr-Contaminated Soils. Journal of Plant Nutrition.30: 289-308.

Suthar, S.S., Watts, J., Sandhu, M., Rana, S., Kanwal, A., Gupta, D. and Meena, M.S.2005.Vermicomposting of kitchen waste by using Eisenia foetida (SAVIGNY). Asian Journal of Microbiology, Biotechnology and Environmental Sciences. 7: 541-544.

Usman, A.R.A., Alkredaa, R.S., and AlWabel, M.I.2013. Heavy metal contamination in sediments and mangroves from the coast of Red Sea: Avicennia marina as potential metal bioaccumulator. Ecotoxicology and Environmental Safety.97: 263-270.

Walker, D. J., Clemente, R. and Bernal, M. P. 2004. Contrasting effects of manure and compost on soil $\mathrm{pH}$, heavy metal availability and growth of Chenopodium album L. in a soil contaminated by pyritic mine waste. Chemosphere. 57(3): 215-224.

Wang, K., Gao, F., Ji, Y.X., Liu, Y., Dan, Z.W., Yang, P.F., Zhu, Y.G. and Li, S.Q. 2013. ORFH79 impairs mitochondrial function via interaction with a subunit of electron transport chain complex III in Honglian cytoplasmic male sterile rice. New Phytologist. 198: 408-418

Wani, P. A., Khan, M. S. and Zaidi, A. 
2006.An evaluation of the effects of heavy metals on the growth, seed yield and grain protein of lentil in pots. Annals of Applied Biology.27:23-24.

Yadav, R. L., Dwivedi, B. S. and Pandey, P. S. 2000. Rice-wheat cropping system: assessment of sustainability under green manuring and chemical fertilizer inputs. Field Crops Research. 65(1): 15-30.

Yassen, A.A., Nadia, B.M. and Zaghloul, M.S. 2007. Role of some organic residues as tools for reducing heavy metals hazards in plant. World Journal of Agricultural Sciences. 3(2): 204-209. Yuji, S., Matsumoto, S. and Sadakata, M. 2004. Alkali soil reclamation with flue gas desulfurization gypsum in China and assessment of metal content in corn grains. Soil and Sediment Contamination (formerly Journal of Soil Contamination). 13(1): 65-80.

Zheljazkov, V.D. and Warman, P.R. 2004. Application of high - $\mathrm{Cu}$ compost to dill and peppermint. Journal of Agricultural and Food Chemistry. 52: 2615-2622.

\section{How to cite this article:}

Ramya Krishna Koka, P.K. Sharma, Jiten Behera and Gayathri Chalageri. 2019. Remediation of Chromium Toxicity by FYM and Vermicompost in Rice (Oryza sativa). Int.J.Curr.Microbiol.App.Sci. 8(02): 1906-1922. doi: https://doi.org/10.20546/ijcmas.2019.802.222 